Cahiers $d u$ MONDE RUSSE

\section{Cahiers du monde russe}

Russie - Empire russe - Union soviétique et États indépendants

$43 / 4 \mid 2002$

Intellectuels et intelligentsia

\title{
Lennart Samuelson, Plans for Stalin's war machine
}

\section{Paul Gregory}

\section{OpenEdition}

\section{Journals}

\section{Electronic version}

URL: https://journals.openedition.org/monderusse/4033

DOI: 10.4000/monderusse.4033

ISSN: $1777-5388$

\section{Publisher}

Éditions de l'EHESS

\section{Printed version}

Date of publication: 30 December 2002

Number of pages: $732-734$

ISBN: 2-7132-1796-2

ISSN: $1252-6576$

\section{Electronic reference}

Paul Gregory, "Lennart Samuelson, Plans for Stalin's war machine", Cahiers du monde russe [Online], 43/4 | 2002, Online since 17 June 2009, connection on 02 September 2022. URL: http:// journals.openedition.org/monderusse/4033 ; DOI: https://doi.org/10.4000/monderusse.4033

This text was automatically generated on 2 September 2022

All rights reserved 


\title{
Lennart Samuelson, Plans for Stalin's war machine
}

\author{
Paul Gregory
}

\section{REFERENCES}

Lennart SAMUELSON, Plans for Stalin's war machine. Tukhachevskii and militaryeconomic planning 1925-1941. Basingstoke, MacMillan, 2000, 267 p.

Lennart Samuelson has written a comprehensive account of Soviet military planning from the mid 1920s until the outbreak of the Second World War. He uses materials from the formerly secret archives to obtain a behind-the-scene's view of the political economy of Soviet military planning. Samuelson's book is the fourth significant book on the Soviet military economy published over the past six years (see Simonov, Barber and Harrison), providing the most detailed account of the origins of the Soviet militaryindustrial complex. ${ }^{1}$ It also links to Mark Harrison's study of the Soviet military economy during World War II. ${ }^{2}$ As a consequence of these publications, we have moved from a patchy knowledge of top-level decision making in the Soviet military complex to a body of knowledge that compares with the civilian economy.

Samuelson's story focuses on three pivotal figures - Stalin, K.Voroshilov, and M. Tukhachevskii. Voroshilov, the commissar of defense, is presented as a professional bureaucrat, easily intimidated; Tukhachevskii as the far-sighted military strategist, who designed the modern Soviet Red Army; and Stalin as the dictator who vacillates between admiration and scorn for the independent-minded Tukhachevskii, who suffered the typical fate of strong-willed leaders under Stalin - execution. As the title suggests, the author focuses on the creation of the system of military planning. Samuelson explains that military planning was comprised of "plans for war" and "mobilization requests" that were only loosely integrated into national economic plans. The plans for war were devised by the military, largely under Tukhachevskii's direction. These plans spelled out the needs of the military during the first year of war and then for subsequent years of 
war. National economic plans and mobilization requests were supposed to be based on these plans for war. Drawing up the various plans of war was complicated by the fact that, although there was a consensus that war was inevitable, the enemy could not be identified so easily. Thus various plans of war anticipated Japan, Poland, or Romania (backed by France) as potential combatants. Only late in the game was the eventual protagonist - Nazi Germany - identified. Not knowing the enemy or the duration of hostilities made military planning extremely uncertain, raising doubts that military planning was even possible. The actual planning of defense eventually fell upon the defense industry administration of Gosplan, which remained under civilian rule, despite the military's attempt to direct it. The actual military plan was, in reality, comprised of the defense budget, which had to compete for resources with other budget claimants and of mobilization orders that were negotiated between the military and the defense industry administration of the commissariat of heavy industry. The relationship between the military and the commissariat of heavy industry under S. Ordzhonikidze was complex. The military supported Ordzhonikidze's claims for more resources for basic heavy industries, under the assumption that military power depends on steel, coal, and transportation equipment. The military and Ordzhonikidze, however, disagreed on specifics with Ordzhonikidze attempting to avoid difficult defense orders.

The mobilization orders were the true defense plans, just as the quarterly plans were the true operational plans of the economy. Despite the priority of defense orders, there were dramatic failures in their fulfillment, such as disastrous results for tank production in 1932, and the massive failure to fulfill the 1937 mobilization requests. There was no first five-year plan for defense, and the second five-year plan for defense was drafted by Gosplan's defense sector with great difficulty. Much defense planning took place outside of the formal planning hierarchy in informal meetings in Stalin's study. Military budgets were not met, and the impression that one gains from Samuelson is that planning for war was as chaotic as planning for industrialization. ${ }^{3}$ Military planning was complicated not only by the natural uncertainty of international politics, but also by secrecy issues. Often plans for war were prepared in only three copies that ordinary civilian planners never saw.

4 Samuelson has written an admirable book. It is concise and provides a coherent account of the manner in which the top Soviet leadership stumbled towards a system of military planning. Several decades back, we knew virtually nothing about this subject. The team headed by Abram Bergson to calculate Soviet growth had to rely on bits and pieces of random information to estimate defense spending. ${ }^{4}$ Samuelson now routinely provides detailed breakdowns of defense budgets, production targets, and the like, which can be used to revise these calculations. If Samuelson's book contains a major surprise it is that plan failures in the defense sector may have been just as large as in the civilian sector despite the overwhelming priority of defense. Supposedly, the strength of the administrative command system was its ability to meet priority targets; yet Samuelson shows that general failures of the civilian economy translated into major failures in the defense sector. 


\section{NOTES}

1. Nikolai Simonov, Voenno-promyshlennyi kompleks SSSR v 1920-1950e gody (Moscow: Rosspen, 1996); John Barber and Mark Harrison, eds, The Soviet defense-industry complex from Stalin to Khrushchev (London: MacMillan, 1998).

2. Mark Harrison, Accounting for war: Soviet production, employment, and defense burden, 1940-45 (New York : Cambridge University Press, 1996).

3. For an account of civilian planning also based on the archives, see: Paul Gregory, The political economy of Stalinism (Cambridge, forthcoming), chap. 8.

4. Abram Bergson, The real national income of Soviet Russia since 1928 (Cambridge, MA: Harvard University Press, 1961). 